\title{
CARA ORANGTUA KRISTEN DALAM MENDIDIK ANAK
}

\author{
Dorlan Naibaho \\ Institut Agama Kristen Negeri Tarutung \\ Email: naibaho_dorlan@yahoo.com
}

\begin{abstract}
Abstrak-Tujuan penulisan artikel ini adalah untuk menentukan pola yang tepat bagi orangtua dalam mendidik anak di lingkungan keluarga. Dalam pembinaan iman terhadap anak, orang tua bertanggung jawab penuh tidak hanya kepada anak tetapi juga kepada Allah. Seiring dengan pesatnya perkembangan tehknologi saat ini, banyak orangtua mendidik anak dengan cara otoriter yaitu dengan memaksa anak melakukan sesuai keinginan orangtua. Sebaiknya hal ini hendaklah dimengerti terlebih dahulu oleh setiap orang tua, sehingga di dalam mendidik, mengasuh dan membimbing dapat dilakukannya dengan pengertian yang baik dan benar sehingga tidak terjadinya kekerasan atau penindasan, pemaksaan kepada anak di dalam melaksanakan hal-hal yang berkaitan dengan tuntutan orang tua. orang tua hanyalah mendidik dan membimbing anak untuk bisa memiliki pengetahuan secara baik dan bertanggung jawab sebagai bekal bagi anak di kemudian hari, serta tugas mengawasi anak dalam perkembangannya sampai kelak ia dewasa dan mampu berdiri di atas kemandiriannya sendiri secara baik dan bertanggung jawab. “Apa yang kuperintahkan kepadamu pada hari ini haruslah engkau perhatikan. Haruslah engkau mengajarkannya berulang-ulang kepada anak-anakmu dan membicarakannya apabila engkau duduk di rumahmu, apabila engkau sedang dalam perjalanan, apabila engkau berbaring dan apabila engkau bangun." (U1. 6:6-7).

Kata kunci : orangtua, mendidik, anak
\end{abstract}

\section{PENDAHULUAN}

Dalam mendidik anak tentu tidak telepas dari kemampuan orang tua baik itu dari segi pengetahuan maupun dari segi ekonomi, keduanya saling berkaitan. Mendidik anak membutuhkan pengetahuan yang baik dari orang tua agar dalam mengarahkan anak menuju proses pendewasaan diri agar tidak salah arah. Oleh karena itu orang tua haras memperlengkapi diri dengan baik terutama dari segi pengetahuan mengenai pola mendidik anak. Orang tua harus menyadari keterbatasan yang ada pada dirinya dan mau membuka diri untuk belajar menjadi orang tua yang memiliki pengetahuan yang baik dalam mendidik anak-anaknya dan tentunya semua dilakukan atas dasar cinta kasih demi perkembangan masa depan anak tersebut. Orangtua harus mendidik anak-anak untuk mengenal ajaran yang baik. Jangan biarkan anak-anak hanyut dalam kesalahan. Dalam hal ini teguran dari orang tua diperlukan agar anak-anak menyadari kesalahannya. Orang tua yang membiarkan anak-anak hanyut dalam kesalahan tanpa teguran adalah orang tua yang tidak menjalankan peran dan fungsinya dengan penuh tanggung jawab. Suatu hal yang penting bagi orang tua adalah bahwa menerima anak sebagai pemberian Allah yang adalah anugerah bukan suatu beban dan menerimanya secara bertartanggungjawab. Orang tua memainkan kembali peranan pencipta yaitu melahirkan (bagi seorang ibu), memelihara, dan membesarkan anak-anak untuk mengabdi kepada Tuhan. Anugerah Allah bukan saja hak yang harus diterima tetapi juga merupakan kewajiban dan tanggung jawab yang harus dilaksanakan dengan sebaikbaiknya.

Menurut, Anwar (2003 : 297) Orang tua adalah ayah dan ibu kandung yang dianggap tua dan perlu dihormati, yang 
memiliki kewenangan mutlak dari Allah untuk membesarkan dan mendidik anakanaknya secara bertanggung jawab.

Dalam Amsal 22: 6 "Didiklah orang muda menurut jalan yang patut baginya, maka pada masa tuanyapun ia tidak akan menyimpang dari jalan itu". Didikan orang tua pada masa muda akan mempengaruhi kehidupan anak-anak dikemudian hari. Anak-anak harus dididik pada jalan yang seharusnya yaitu dalam kebenaran, kesalehan dan menurut perkembangan jasmani dan mental si anak. Demikian pula besar arti anak-anak dalam perjanjian baru sehingga Yesus Kristus sendiri berkata: "Biarkan anak-anak itu datang kepadaKu jangan menghalang-halangi mereka, sebab orang-orang yang seperti inilah yang empunya kerajaan sorga (Matius 19 : 13-15; Markus 10 : 13 - 16; Lukas 18 : 15-17) anak-anak berhak mendengar didikan tentang pengenalan akan Tuhan dan hakekat mereka sebagai orang Kristen.

Menurut Sidjabat (2008 : 17- 38) para ahli psikologi dan pendidikan anak pada umumnya menyatakan bahwa lingkungan dan gen yang paling banyak mempengaruhi pembentukan watak, iman, dan tata nilai adalah keluarga asal (the family of origin). Misal, Robert Coles mengakui bahwa keluarga merupakan lingkungan primer dalam memebentuk kecerdasan moral anak. Sebelum anak menerima pengaruh dari teman sebaya dan guru di sekolah, ia sudah lebih dulu dibentuk ibu dan ayahnya, serta dipengaruhi saudara maupun pengasuhnya. Dengan kata lain, bagi anak, keluarga asal dianggap sangat berharga, dengan dinamakan dan kondisi apapun.

\section{METODE}

Dalam penulisan artikel ini metode yang digunakan adalah deskriptif kualitatif pada literature (pustaka). Penulis merujuk kepada pendapat para ahli tentang bagaimana pola orangtua Kristen dalam mendidik anak-anaknya. Melalui pendapat para ahli tersebut, penulis menemukan konsep dari orang tua Kristen mendidik anak-anaknya sesuai dengan nilai-nilai Kristiani.

\section{PEMBAHASAN}

Orangtua memiliki peranan penting dalam meningkatkan kualitas sumber daya manusia. Pendidikan moral dalam keluarga perlu ditanamkan pada sejak dini pada setiap individu. Walau bagaimana pun, selain tingkat pendidikan, moral individu juga menjadi tolak ukur berhasil tidaknya suatu pembangunan. Perkembangan ilmu pengetahuan dan teknologi memegang peranan penting serta sangat mempengaruhi perkembangan sikap dan intelektualitas generasi muda sebagai penerus bangsa. Keluarga, kembali mengambil peran penting dalam meningkatkan kualitas sumber daya manusia. Berbagai aspek pembangnan suatu bangsa, tidak dapat lepas dari berbagai aspek yang saling mendukung, salah satunya sumber daya manusia. Terlihat pada garis-garis haluan negara bahwa penduduk merupakan sumber dyaa manusia yang potensial dan produktif bagi pembangunan nasional. Hal ini pun tidak dapat terlepas dari peran serta keluarga sebagai pembentuk karakter dan moral individu sehingga menjadi sumber daya manusia yang berkualaitas.

Menurut Akbar (2001) Keluarga bagi seorang anak merupakan lembaga pendidikan non formal pertama, dimana mereka hidup, berkembang dan matang. Di dalam sebuah keluarga, seorang anak pertama kali diajarkan pada pendidikan. Dari pendidikan dalam kelaurga tersebut anak mendapatkan pengalaman, kebiasaan, keterampilan berbagai sikap dan bermacammacam pengetahuan.

Menurut Effendi (1995) keluarga memiliki peranan utama di dalam mengasuh anak, di segala norma dan etika yang 
berlaku di dalam lingkungan masyarakat, dan budayanya dapat diteruskan dari orang tua kepada anaknya dari generasi-generasi yang disesuaikan dengan perkembangan masyarakat.

Keberhasilan pembangunan suatu bangsa sangat memerlukan adanya sumber daya manusia yang berkualitas baik. Untuk mendapatkan sumber daya manusia yang berkualitas baik tentunya memerlukan berbgai macam cara. Salah satu diantanya adalah melalui pendidikan. Pendidikan baik formal maupun informal. Pendidikan moral dalam keluarga merupakan salah satunya. Walaupun memiliki tingkat pendidikan yang tinggi, tetapi rendah dalam hal moralitas, individu tidak akan berarti dimata siapa pun. Pendidikan moral dimulai dari sebuah keluarga yang menanamkan budi pekerti luhur dalam setiap interaksinya. Sumber daya manusia berkualitas dapat dilihat dari kelaurganya. Bukan hanya keluarga mampu dari segi amteri, yang dapat meningkatkan kualitas individunya melalui tambahantambahan materi pembelajaran di luar bangku sekolah. Akan tetapi, keluarga sederhana dan di desa pun dapat menjamin kualitas sumber daya manusianya. Kualitas sumber daya dan keluhuran budi pekerti merupakan hasil tempaan orang tua. Pendidikan mencakup beragam aktifits yang bertujuan agar anak dapet berkembang secara optimal dan dapat bertahan hidup dengan baik. Prinsip pendidikan menurut Houghugi tidak menekankan pada siapa (pelaku) namun lebih menekankan pada tujuan dari perkembangan dan pendidikan anak. Oleh karenanya tujuan pendidikan meliputi pendidikan fisik, pendidikan emosi dan pendidikan sosial.

a. Pendidikan fisik mencakup semua aktifitas yang bertujuan agar anak dapat bertahan hidup dengan baik dengan menyediakan kebutuhan dasarnya

b. Pendidikan emosi mencakup pendamping ketika anak mengalami kejadian-kejadian yang tidak menyenangkan seperti merasa terasing dari teman-temannya, takut, atau mengalami tekanan mental. Pendidikan emosi ini mencakup pendidikan agat anak merasa dihargai sebagai seorang individu, mengetahui rasa dicintai, serta memperoleh kesempatan untuk menentukan pilihan dan utnuk megetahui resikonya. Pendidikan emosi ini bertujuan agar anak mempunyai kemampuan yang stabil dan konsisten dalam berinteraksi dengan lingkunnganya.

c. Sementara itu, pendidikan sosial bertujuan agar anak tidak merasa terasing dari lingkungna sosialnya yang akan berpengaruh terhadap perkembangan anak pada masa- masa selanjutnya.

Menurut Amin (1993 : 104) cara mendidik anak ada tiga macam, yaitu:

1) Pola Asuh Demokratis

Pola asuh demokratis ditandai dengan adanya pengakuan orang tua terhadap kemampuan anak, anak diberi kesempatan untuk tidak selalu tergantung kepada orang tua. Orang tua sedikit memberi kebebasan kepada anak untuk memilih apa yang terbaik bagi dirinya, anak didengarkan pendapatnya, dilibatkan dalam pembicaraan terutama yang menyangkut dengan kehidupan anak itu sendiri. Anak diberi kesempatan untuk mengembangkan kontrol internalnya sehingga sedikit demi sedikit berlatih untuk bertanggung jawab kepada diri sendiri. Anak dilibatkan dan diberi kesempatan untuk bertpartisipasi dalam mengatur hidupnya. Orang tua yang mendidik anaknya dengan sikap demokrasi memiliki ciri-ciri sebagai berikut:

Komunikasi Orang Tua dan Anak

Sikap demokrasi itu berkembang dari kebiasaan komunikasi di dalam rumah tangga, komunikasi berperan sebagai sarana pembentukan moral anak. Melalui interaksi dengan orang tuanya, anak mengetahui 
tentang apa yang baik dan apa yang buruk, apa yang boleh dilakukan dan apa yang tidak boleh dilakukan.

Menurut Setiawan (2000: 69-71) dalam membangun komunikasi dengan anak harus memperhatikan prinsip-prinsip di bawah ini:

1. Menyediakan Waktu

Dewasa ini orang tua yang bekerja di luar rumah banyak waktunya untuk menjalankan pekerjaannya, sehingga waktu untuk anak-anaknya berkurang dan minim sekali bisa komunikasi dengan anaknya. Paling tidak anak harus ditelepon orangtuanya dengan membicarakan hal-hal yang menyenangkan bagi anak dan bisa mendekatkan hubungan orangtua dengananak. Dalam hal ini orang tua yang rela mengorbankan waktunya untuk berkomunikasi dengan anak-anaknya berarti orang tua tersebut sudah mengasihi dan memperhatikan anaknya.

2. Berkomunikasi secara pribadi

Berkomunikasi secara pribadi berarti komunikasi diadakan secara khusus dengan anak, sehingga akan dapat mengetahui perasaan yang sedang dialami oleh anaknya, baik perasaaan ketika anak senang, marah dan gembira.

3. Menghargai anak

Orang dewasa sering meremehkan anak, baik dalam keadaan sadar atau tidak sadar. Padahal seiring dengan kemajuan IPTEK besar kemungkinan kemampuan seorang anak dapat melebihi orang dewasa, maka usahakanlah orang tua untuk menghargai anak dan menerima pendapat anak.

4. Mengerti anak

Dalam berkomunikasi dengan anak, usahakan untuk mengenal dunia anak memandang dari posisi mereka untuk mendengarkan ceritanya dan apa dalihnya serta mengenai apa yang menjadi suka duka, kegembiraan, kesulitan, kelebihan serta kekurangan anak, orang tua yang sering berkomunikasi dengan anak, hubungannya akan menjadi lebih erat dengan anak dan apabila anaknya mempunyai masalah akan mudah diselesaikan.

5. Mempertahankan hubungan

Komunikasi yang baik selalu didasarkan pada hubungan yang baik, orang tua yang selalu menjaga hubungan yang baik dengan anak dan menganggap anaknya sebagai teman, sehingga berkait kedekatan mereka, anaknya dapat mengutarakan isi hatinya dengan terbuka.

\section{Menerima Kritik}

Sikap demokrasi juga ditandai dengan adanya sikap terbuka antara orang tua dan anaknya, teknik disiplin demokrasi menggunakan penjelasan, penalaran dan diskusi, untuk membantu anak mengapa perilaku tertentu itu diharapkan. Hubungan yang akrab dan harmonis antara anak-anak dengan orang tua sangatlah penting dalam kehidupan suatu keluarga. Bahkan jika perlu orangtua harus rela mengorbankan kepentingannya agar bisa memberikan waktu berharganya kepada buah hatinya. Anak-anak adalah generasi penerus orangtua yang harus diberikan kasih sayang dan bimbingan agar bisa tumbuh dan berkembang menjadi pribadi yang sesuai dengan harapan orangtua dan harapan agama.

Menurut Hurloch (1978 : 93) pola asuh demokratis ini akan berpengaruh pada sifat dan kepribadian anak. di antaranya: bersikap bersahabat, percaya kepada diri sendiri, mampu mengendalikan diri, memiliki rasa sopan, mau bekerja sama, memiliki rasa ingin tahu yang tinggi, mempunyai tujuan dan arah hidup yang jelas dan berorientasi terhadap prestasi.

Menurut Yusuf (2003: 52) Pola asuh secara demokratis sangatlah positif 
pengaruhnya pada masa depan anak, anak akan selalu optimis dalam melangkah untuk meraih apa yang diimpikan dan di citacitakan. Pendidikan keluarga dikatakan berhasil manakala terjalin hubungan yang harmonis antara orang tua dengan anak, baik atau buruk sikap anak dipengaruhi oleh bagaimana orang tua menanamkan sikap. Pertama, dalam konsep diri yang mencakup pengenalan diri, penerimaan dan penghargaan diri. Kedua, dalam aspekaspek pola-pola komunikasi, termasuk cara berbicara, kata dan bahasa yang digunakan serta pemakaian bahasa symbol atau bahasa tubuh. Tentang corak komunikasi terkait di dalamnya entah bersifat tertutup atau terbuka, komunikasi yang kasar atau sopan, yang emosional atau rasional. Seperti telah disinggung di atas, orangtualah yang menanamkan pola-pola dan ketrampilan berkomunikasi secara baik dan benar bagi anak-anak mereka. Anak-anak mendengan orangtuanya berbicara. Anak-anak juga melihat gerak tubuh orangtua ketika menegaskan sesuatu atau ketika marah dan gembira. Anak-anak tentunya menerima arahan dan nasihat serta latihan dari ayah, ibu, atau pengasuhnya tentang cara yang tepat menyatakan perasaan dan isi hati, cara menamai sesuatu atau memanggil orang lain.

Menurut Syamsu Yusuf pola asuh demokratis ini akan berpengaruh pada sifat dan kepribadian anak. di antaranya:

1. Bersikap bersahabat.

2. Percaya kepada diri sendiri.

3. Mampu mengendalikan diri.

4. Memiliki rasa sopan.

5. Mau bekerja sama.

6. Memiliki rasa ingin tahu yang tinggi.

7. Mempunyai tujuan dan arah hidup yang jelas.

8. Berorientasi terhadap prestasi.

1) Pola asuh demokrasi merupakan pola asuh yang paling baik. Dimana orangtua bersikap friendly dan anak bebas mengemukakan pendapatnya. Disini orangtua lebih mau mendengar keluhan dari anaknya, mau memberikan masukan.

\section{2) Pola Asuh Otoriter}

Pola asuh otoriter merupakan cara mendidik anak dengan menggunakan kepemimpinan otoriter, kepemimpinan otoriter yaitu pemimpin menentukan semua kebijakan, langkah dan tugas yang harus dijalankan. Menurut Hurloch (1978: 93) bahwa Pola asuh otoriter adalah pola asuh yang ditandai dengan cara mengasuh anakanak dengan aturan yang ketat, sering kali memaksa anak untuk berperilaku seperti dirinya (orang tua), kebebasan untuk bertindak atas nama diri sendiri dibatasi, anak jarang diajak berkomunikasi dan diajak ngobrol, bercerita, bertukar pikiran dengan orang tua. Orang tua malah menganggap bahwa semua sikap yang dilakukan itu sudah benar sehingga tidak perlu minta pertimbangan anak atas semua keputusan yang mengangkat permasalahan anakanaknya.

Pola asuh yang bersifat otoriter ini juga ditandai dengan hukuman-hukuman yang dilakukan dengan keras, anak juga diatur dengan berbagai macam aturan yang membatasi perlakuannya. Perlakuan seperti ini sangat ketat dan bahkan masih tetap diberlakukan sampai anak tersebut menginjak dewasa. Menurut Yusuf (2011: 51 ) Ciri-ciri pola asuh otoriter di antaranya:

a) Hukuman yang keras

b) Suka menghukum secara fisik

c) Bersikap mengomando

d) Bersikap kaku (keras)

e) Cenderung emosional dalam bersikap menolak

f) Harus mematuhi peraturan-peraturan orang tua dan tidak boleh membantah.

Akibatnya anak cenderung memiliki ciri-ciri sebagai berikut :

a) Mudah tersinggung 
b) Penakut

c) Pemurung tidak bahagia

d) Mudah terpengaruh dan mudah stress

e) Tidak mempunyai masa depan yang jelas

f) Tidak bersahabat

g) Gagap (rendah diri).

Kewajiban orang tua adalah menolong anak dalam memenuhi kebutuhan hidupnya, akan tetapi tidak boleh berlebihlebihan dalam menolong sehingga anak tidak kehilangan kemampuan untuk berdiri sendiri nantinya dimasa yang akan datang. Keluarga harus memahami sejumlah kebutuhan dasar anak. Keluarga tidak boleh hanya mendesak agar anak berperilaku baik, hormat dan taat kepada orangtuanya. Sementara sikap dan tindakan mereka berlaku sarkastik, kasar, bahkan kejam terhadap anaknya. Sikap hormat anak kepada orangtua memang sebuah nilai moral yang perlu ditanamkan. Akan tetapi janganlah hal itu dianggap dapat ditumbuhkan orang tua melalui pendekatan otoriter atau pemaksaan. Ini sering kita temukan dalam masyarakat dan budaya Indonesia. Padahal, untuk hormat kepada orangtuanya, anak membutuhkan bimbingan, asuhan, arahan, ajaran, dan latihan. Sikap hormat kepada orangtua seharusnya berkembang dari dalam diri anak itu sendiri dari hasil menyaksikan perkataan, sikap dan perilaku orangtuanya. Kekaguman mereka terhadap ayah dan ibu yang mengasihi akan secara perlahan melahirkan sikap respek.

Berikut ini ialah anak mempunyai kebutuhan (needs) yang mestinya dipikirkan, diperhatikan, bahkan dipenuhi orangtuanya. Jika tidak, orangtua menuai hasil yang tidak diharapkan. Seperti yang dikatakan firman Tuhan, apa yang ditabur orang, itu akan dituai kelak (Gal. 6:7-8).

Menurut Dr. Bruce Narramore dalam karyanya Mengapa Anak Berkelakuan Buruk (1981), karakter buruk terbentuk dan berkembang pada diri anak disebabkan oleh kekeliruan orang tua dalam membesarkan anak- anaknya. Orang tua tidak mengerti cara yang sehat dalam memenuhi kebutuhan anak seperti yang telah didesain Allah. Akibat itu terpenuhinya kebutuhan itu, anak mencari upayanya sendiri dan seterusnya terbentuklah watak yang menjadi ciri khasnya.

a. Pertama, anak membutuhkaan kasih (love). Anak kecil ingin sekali dikasihi orangtuanya, terutama melalui sentuhan fisik, dekapan, pelukan, dan sanjungan. Karena perkara ini, anak berusaha menaruk perhatian orangtua dengan sikap pasif (berdiam diri) atau bersikap agresif seperti menganggu adik dan kakanya atau melakukan kegiatan merusak barang mainannya. Bila kebutuhan ini dirasakan dan tetap tidak terpenuhi, akibatnya anak bertumbuh dalam rasa kesepian, menarik diri dan terisolasi, menderita stress, bahkan depresi.

b. Kedua, anak membutuhkan percaya diri (self confidence). Anak usia balita khususnya menyatakan adanya kebutuhan ini dengan memainkan kuasa dan pengendalian. Mereka memperlihatkan sikap memberontak terhadap otoritas orantua. Anak melakukan hal itu karena ingin "merdeka" atau menunjukkan otonomi, sebagai pribadi yang berbeda dari ayah dan ibunya. Seharusnya orang tua memberi ruang bagi anak untk menyatakan pendapat, menunjukkan kemampuan atau kebolehannya. Akan tetapi karena tidak tahu, banyak orangtua menyuruh anaknya diam saja, agar tidak rebut dan sekali-kali jangan membantah otoritas orangtuanya. Karena kebutuhan ini dirasa tetap tidak terpenuhi, anak bertumbuh dalam perasaan lemah, tak berdaya, rendah diri di kemudian hari.

c. Ketiga, anak membutuhkan harga diri (self esteem). Anak usia Sekolah Dasar 
(SD) khususnya menyatakan adanya kebutuhan ini dengan cara berusaha perfeksionis atau selalu ingin serba sempurna, suka memamerkan kebolehannya, dan menjadi sangat penurut kepada otoritas. Sikap penurut itu direfleksikan karena anak ingin mendapat penghargaan dari orangtuanya. Akan tetapi, karean dirasakan bahwa penghargaan dan pengakuan orang tua tidak terpenuhi, akibatnya pada diri anak bertumbuh perasaan tidak berharga, tidak berguna, tidak memiliki sesuatu yang baik.

d. Keempat, anak membutuhkan aktivitas yang membangun (competed). Anak memeperlihatkan adanya kebutuhan ini dengan melakukan kegiatan negative atau merusak. Misalnya, ayah sedang memperbaiki sesuatu. Kemudian, anak mendekat dan mulai memegang peralatan yang digunakan ayahnya. Dengan menganggu, sebenarnya anak ingin terlibat dengan pekerjaan si ayah atau dalam kegiatan positif rumahnya bersama dengan orangtua. Anak ingin dilibatkan atau berpartisipasi. Karena tetap merasa tidak terpenuhi, hasilnya dalam diri anak bertumbuh rasa bosan dan gelisah. Anak marah, menggerutu. Untuk memenuhi itu sebenarnya orang tua dapat saja memberi kegiatan lain yang dapat dikerjakan anaknya aktifitas yang tidak berbahaya. Masalahnya orang tua tidak mau repot untuk memeberikan perhatian, memberi petunjuk dan latihan dasar karena dianggap anaknya hanya menganggu konsentrasinya.

e. Kelima, anak membutuhkan rasa aman (safety and security). Anak kecil yang ditakut- takuti dan diancam jika tidak berbuat seperti yang dikehendaki orang tua atau pengasuhnya, dapat merasa tidak aman dan tidak nyaman. Misalnya anak ingin ditemani sejenak sebelum tidur tetapi ditolak orang tua, malah dikunci di ruang gelap. Cara anak itu memeohon mungkin disertai rengekan dan tangisan yang membuat pengasuhnya kesal. Anak yang ditinggalkan orang tua atau pengasuhnya di rumah maupun di kamarnya dalam waktu cukup lama tanpa penejelasan kemana ia pergi dapat menimbulkan perasaan tidak aman baginya. Trauma. Menurut Bruce Narramore, apabila kebutuhan rasa aman ini tidak terpenuhi, kelak anak menyatakan enggan sikap kebencian, bahkan balas dendam. Ada juga anak yang menyatakan dengan membentuk berbagai reaksi seperti menyendiri, menyerah, depresi, membela diri (memenarkan diri) meskipun salah dan mengusahakan kompesasi berlebihan. Anak yang besar dengan otoriter anak seperti ini biasanya tidak bahagia, paranoid atau selalu berada dalam ketakutan, mudah sedih dan tertekan, senang berada di luar rumah, benci orangtua, dan lain-lain

Dasar alkitabiah tanggung jawab orangtua terhadap anak- anaknya.

1. Mendisiplin anak - anak (Ams. 13: 24; 19:18; 23:13; 29:17).Setiap anak membutuhkan disiplin. Hal ini berarti harus ada peraturan, kebiasaan, batasan kelakuan dan akibat, harus ada nasehat, orang tua menganjurkan kelakuan yang baik dan juga memperbaiki kelakuan yang tidak baik. Jangan lakukan disiplin untuk menghukum anak. Jika anak menunjukkan perilaku buruk, hadapi dengan tenang dan kendali diri. Coba untuk memahami alasan di balik perilaku anak dan bagaimana perasaan anak. Tangani situasi hingga anak akan mendapat pelajaran dari perilakunya tersebut.

Cara menerapkan disiplin

a. Gunakan alat yang tepat Ams 29:15, $13: 24 ; 22: 15,23: 13-14$. Rasa sakit saat didisiplin akan membawa anak pada 
pengertian bahwa upah dosa adalah maut. Ams 20:30 pukulan dapat membersihkan lubuk hati

b. Anda sendiri harus selalu dalam keadaan terkendali, penerapan pukulan bukanlah suatu kesempatan untuk melampiaskan frustrasi, ketegangan ataupun amarahnya sendiri, Yak 1:20

c. Jangan menunda untuk mendisiplin Pngkh 8:11, Ams 19:18

d. Pastikan bahwa anak tahu apa yang menjadi kesalahannya sebelum ia disiplin. II Sam 12, Tuhan menegur Daud lewat nabi Natan. Siapa menyembunyikan pelanggarannya tidak akan beruntung, Ams 28:13

e. Posisikan anak dengan posisi yang tepat. Amsal 15:10 , pilihlah bagian pantat yang empuk. Jangan menyentuh bagian wajah sama sekali dalam mendisiplin misalnya dengan menampat, menjewer, menyelentik mulut, dan lain-lain, hal ini akan merusak gambar diri anak-anak.

f. Katakan prilaku yang buruk, bukan 'anak yang buruk'. Koreksi yang baik harus mendatangkan perubahan, setiap koreksi harus beralasan, misalnya "dasar anak nakal, tak tahu diuntung !" itu bukan koreksi yang baik karna menyerang pribadi anak, bukan prilakunya, contoh yang benar adalah "seharusnya kamu belajar taat! Tuhan senang jika kita taat!"

g. Selamatkan harga diri anak anda. Katakan tujuan anda adalah agar kesalahan yang sama tidak terulang lagi, nyatakan keyakinan anda bahwa anak anda dapat berubah. Katakanlah bahwa disiplin ini adalah terpaksa karma kasih saudara kepadanya. Peluk dia kembali.

h. Memuji di hadapan umum, mendisiplin secara pribadi

i. Ajak anak meminta ampun kepada Tuhan dalam doa dan membereskan langsung masalah-masalah yang berkaitan dengan orang lain. j. Pendisiplinan menggunakan rotan hanya sampai anak berumur 7 tahun saja, selebihnya anak-anak didisiplin dengan sangsi, misalnya jika melanggar peraturan, disangksi tidak mendapat uang jajan selama 2 hari, atau tidak boleh melihat kartun kesayangannya selama 2 hari, dst. Mengapa setelah usia diatas tahun, tidak diterapkan disiplin rotan lagi? karna setelah umur 7 tahun anak-anak dapat diberi pengertian mengapa ini tidak boleh, mengapa itu tidak boleh, dst. Sedang anak di bawah 7 tahun, yang dibutuhkan dari mereka hanya ketaatan mutlak, tanpa perlu kita menjelaskan panjang lebar mengapa ini tidak baik, mengapa itu baik.

k. Ada kondisi-kondisi dimana anak tidak boleh didisiplin

2. Memiliki kasih sayang kepada anakanaknya (Mzm. 103: 13).Setiap anak membutuhkan kesanggupan mengasihi dan dikasihi. Yang sanggup mempengaruhi dia adalah kasih antara orang tua serta hubungan antara orang tua dan anak.

3. Mencintai atau mengasihi anak- anaknya (Yes. 49:15; Tit. 2:4). Setiap orang ingin dikasihi terlebih seorang anak sangat membutuhkan kasih sayang orangtua dengan cara mendengar keluhan anak.

4. Berdoa untuk anak- anaknya (2 Sam. 12:15; 1 Taw. 29:19; Ayb. 1:5). Doa merupakan unsur penting dalam proses pembentukan keluarga tersebut karena melalui doa dapat memberikan kekuatan dan pengharapan dalam menjalani kehidupan dalam keluarga. Ketika orangtua berdoa menyebutkan nama anak-anaknya maka si anak akan merasa senang.

5. Memelihara atau memperhatikan anakanaknya (Ayb. 42:15; Ams. 19:14).Sebagai orangtua harus dapat mencukupi segala kebutuhan anak.Anak 
juga membutuhkan perhatian berupa kasih sayang melalui sapaan yang indah, lembut, hangat dan bersahaja, canda tawa dan sebagainya

6. Menghormati atau menghargai anakanaknya (Ef. 6:4; Kol. 3:21). Kapanpun anak menunjukkan perasaan negatif atau buruk terhadap suatu masalah, sering kali orang tua langsung menghancurkan perasaan tersebut. Hal ini adalah suatu tindakan terburuk karena anak tidak akan pernah untuk menghadapi perasaan semacam itu dan bagaimana cara untuk menghadapinya. Cara yang benar adalah untuk menerima perasaan anak, baik atau buruk dan membiarkan anak menghadapinya dengan caranya sendiri. Adalah emosi yang akan membuat seseorang mengambil tindakan benar atau salah. Anda dapat memberinya pelukan dan mendengarkan curahan perasaan anak. Lambat laun anak akan belajar untuk mengelola emosinya dengan matang dan dewasa.

7. Mendidik atau mengajar anak-anaknya di jalan Tuhan (Ul. 11:18; 32:46; 2Tim. 1:5). Orang tua berfungsi sebagai pengajar-pengajar yang pertama dalam kehidupan anak-anak. Terutama ayah sebagai kepala keluarga mengumpulkan anak-anak mereka untuk memberikan pengajaran-pengajaran tentang hukum Allah. Orang tua harus mendidik anakanak untuk mengenal ajaran yang baik.

Teladan Orangtua Terhadap Anakanaknya

1. Hagar menunjukkan kasihnya terhadap anaknya (Kej. 21: 14-19)

2. Laban menunjukkan kasihnya terhadap anak- anaknya (Kej. 31:55)

3. Yakub menunjukkan kasihnya kepada anak-anaknya (Kej. 44:20)

4. Daud menunjukkan kasihnya kepada anak-anaknya (2Sam. 13:37-39).

5. Yusuf dan Maria menunjukkan kasihnya kepada anaknya (Luk. 2:41-51)
6. Yairus menunjukkan kasihnya kepada anak (Mrk. 5:21-23)

7. Pegawai istana menunjukkan kasihnya kepada anak (Yoh. 4:46-49)

Keharusan Orangtua Terhadap Anakanaknya:

1. Memperkenalkan anak-anaknya kepada Tuhan Yesus (Mrk. 10:13-16).

Maksud Firman Tuhan disampaikan ialah agar manusia mengenal Allah, mengimani dan mengajarkan kepada orang lain termasuk anak-anaknya. Secara mendasar pengajaran Firman Tuhan banyak diungkapkan dalam Kitab Amsal, supaya anak memiliki pengenalan akan Tuhan dan kehkendakNya. Allah menetapkan orang tua sebagai alat yang penting untuk menyalurkan pengetahuan tentang siapa Allah bagai Allah menyelamatkan umatNya.

Dengan melakukan hal itu, la menyatakan diri-Nya kepada tiap-tiap kepala keluarga sebagai Allah yang menyelamatkan. Orang tua dapat menolong anak-anak rekaman perkembangkan kenyakinan berdasarkan firman Allah, melalui pengajaran, teladan dan bimbingan, yang disertai dengan doa orang tua, dalam menunaikan tugas dan tanggung jawabnya di dalam mendidik dan mengasuh anakanaknya.

Anak-anak akan mengenal Firman Tuhan dengan baik jika hal itu diajarkan oleh orang tua. Oleh karena itu semua ajaran dan didikan yang di terapkan kepada anakanak harus berpedoman pada firman Allah. Cara agar anak terbiasa mengenal Tuhannya dengan baik adalah dengan cara:

1. Mengajarkan berdoa:

Ajarkan berdoa dengan cara yang paling simple atau mudah. Singkat saja katakatanya dan sesuai bahasa anak. Jangan menggunakan bahasa yang terlalu berbelitbelit. Misalkan mau mengajarkan anak berdoa makan. Super Parents bisa membantu anak mengucapkan, "Tuhan, 
(Nama Anak) mau makan. Terima kasih Tuhan atas makanan yang Engkau sediakan. Kiranya Engkau berkati makanan ini. Dalam nama Tuhan Yesus. Amin.”

Yang paling utama yaitu mengajarkan anak untuk selalu berdoa dalam memulai sesuatu. Karena berkat dan hikmat tentu datangnya dari tuntunan Roh Kudus yang tiba dari kedekatan dengan Allah. Doa adalah bentuk komunikasi manusia dengan Tuhan. Filipi 4:6 "Janganlah hendaknya kamu kuatir tentang apapun juga, tetapi nyatakanlah dalam segala hal keinginanmu kepada Allah dalam doa dan permohonan dengan ucapan syukur." Disinilah akar komunikasi pada Allah, yaitu melalui manfaat berdoa bagi orang Kristen.

\section{Mengajar dengan kreatif:}

Ibadah yang kreatif bisa diterima dan dipahami anak dengan baik. SuperParents dan SuperTeacher bisa menggunakan alat peraga berupa film, boneka, drama, maupun permainan agar tidak membosankan.

3. Ibadah keluarga dan sekolah minggu yang menyenangkan:

Ibadah keluarga bukanlah sarana untuk menegur, menasihati, dan menggurui anak. Tetapi bagaimana Super Parents bisa merangkul anak dan menjadi teladan dalam kehidupannya. Begitupun juga di sekolah minggu. Lakukanlah penyampaian firman secara 2 arah, misalnya dengan diskusi. Kakak juga harus sabar ya mendengarkan pendapat anak.Hal ini didukung oleh Kristianto (2006: 151) yang mengatakan ada dua hal penting yang seharusnya dilakukan dalam keluarga agar keluarga tersebut dapat tumbuh secara rohani menuju kepada kedewasaan penuh, yaitu: kebaktian keluarga dan saat teduh. Kebaktian keluarga dilaksanakan secara bersama oleh seluruh anggota keluarga dan seisi rumah. Dalam kebaktian keluarga dilibatkan semua anggota keluarga. Misalnya, ayah menyampaikan Firman Tuhan, ibu memimpin acara, anak-anak sebagai pemimpin pujian. Kebaktian keluarga dapat diadakan pada malam hari sehingga semua anggota keluarga dapat mengikutinya. Apabila memungkinkan dapat diadakan setiap hari atau dua hari sekali dengan waktu 30 menit -60 menit .

\section{Ajari anak melalui teladan:}

Orang tua sebaiknya mengindahkan nasihat rasul Paulus kepada orang Kristen di Roma. Ia menulis kepada mereka, "Apakah engkau, yang mengajar orang lain, tidak mengajar dirimu sendiri? Engkau, yang memberitakan 'Jangan mencuri', apakah engkau mencuri?"Roma 2:21.Nasihat itu masih relevan karena anak-anak lebih mengingat apa yang orang tua lakukan daripada apa yang mereka katakan. Malah, anak-anak akan cenderung mendengarkan apa yang orang tua ajarkan jika orang tua sendiri menjalankan apa yang mereka katakan.

5. Tirulah sikap Yesus terhadap orang-orang yang ia ajar:

Yesus pasti memiliki hal-hal yang paling penting untuk disampaikan. Ia sangat berminat mengetahui pendapat dan perasaan orang-orang yang ia ajar (Matius 17:24, 25; Markus 8:27-29). Demikian pula, orang tua memiliki banyak pelajaran penting untuk diajarkan kepada anak-anak. Tetapi, supaya efektif, mereka perlu meniru Yesus dan menganjurkan anak-anak mengutarakan perasaan mereka dengan leluasa. Orang tua yang meniru Yesus akan mengoreksi anak mereka dengan sabar dan, jika perlu, mengulangi pelajaran yang sama sampai anak-anak benar-benar paham.

2. Mengajar keselamatan terhadap anakanaknya (Kis. 16:1-3) Orang tua mempunyai tugas yang sama dengan para nabi dan imam yaitu menyampaikan dan meneruskan berita tentang karya keselamatan Allah kepada anak-anak. Ini merupakan tugas yang sangat penting dari orang tua, oleh karena itu Allah 
memanggil mereka sebagai orang tua. Memberitahukan kepada anak bahwa tidak ada yang dapat menyelamatkan manusia kecuali Yesus Kristus.

3. Membawa anak-anaknya ke Sekolah Minggu atau Gereja (Mat. 18:1-5)

Sekolah Minggu merupakan salah satu tugas gereja yang membantu orang tua dalampertumbuhan rohani anak. Disana anak-anak akan dididik untuk mengenal kuasa dan kasih Allah, oleh karena itu orang tua perlu membawa anak-anaknya untuk ikut serta ambil bagian menjadi murid-murid sekolah minggu.

4. Mengajar takut dan hormat kepada Tuhan Yesus (Mat. 10:28-32)Orang tua sebagai penuntun dan teladan bagi anakanak. Tugas orang tua seperti ini merupakan suatu pelayanan yang bertujuan bukan untuk kepentingan anakanak saja, melainkan terutama untuk memuliakan nama Tuhan.

Tanggungjawab orang tua memainka peranan penting dalam pelaksanaan pembinaan iman anak dalam suatu keluarga karena orang tua merupakan wakil Allah yang dipilih dan di tetapkan langsung oleh Allah untuk mendidik dan mengasuh anak-anak dalam takut akan Tuhan, orang tua juga merupakan tempat pertama di mana seorang anak bernaung, tumbuh dan berkembang, oleh karena itu orang tua juga harus mencerminkan pola hidup kekristenan yang nantinya dianut oleh anak-anak, sebab hampir setiap orang tua Kristen selalu mengharapkan anak-anaknya menjadi seorang pemuda Kristen yang patuh dan taat kepada Allah. Banyak orang tua tidak menyadari bahwa pola hidup mereka dapat menentukan kepribadian anak-anak mereka.Amsal menyebutkan bahwa permulaan dari segala pengetahuan adalah takut akan Tuhan. Hal ini berarti peranan orang tua dalam mendidik anak menurut Alkitab harus diawali dengan rasa takut akan Tuhan. Ketika orang tua tidak mampu untuk menurunkan rasa takut akan Tuhan kepada anaknya, maka didikan lainnya pun akan sulit untuk diikuti. Orang tua dapat memulainya dengan mengajarkan manfaat membaca Alkitab setiap hari.

5. Mengajarkan Firman Allah secara berkelanjutan (2Tim. 3:15- 17).Kitab Ulangan merupakan bagian akhir kitab Taurat Musa atau Pentateuch. Kitab tersebut mempunyai arti yang besar bagi pembangunan Iman bangsa Israel. Hal itu senada dengan Pembangunan rohani yang dilakukan oleh raja Yosia yang terkenal dengan sebutan reformasi Yosia. Kitab Ulangan sangat memperhatikan hidup iman bangsa Israel yang selalu menghadapi synkretisme atau percampuran agama. Dengan keras kitab Ulangan mengajak Israel agar menjadi bangsa yang memliki ikman yang kuat. Secara khusus pada pasal 6 diingatkan agar takut akan Tuhan dan beribadah kepada-Nya. Bangsa Israel dilarang menyembah kepada allah lain, karena mereka telah dilepaskan dari perhambaan di tanah Mesir. Dalam suasana yang kritis itu bangsa Israel harus membangun iman yang kuat melalui kehidupan keluarga. Orang tua harus mengajarkan firma Tuhan kepada anak-anaknya.Anak-anak Israel harus mengenal siapa Allah dan bagaimana Ia berkarya bagi nenek moyangnya. Pengenalan itu dilakukan melalui pengajaran Firman Tuhan, yang berupa sejarah nenek moyang Israel. Demikian juga hukum-hukum diberikan agar mereka hidup dan bertingkah laku sesuai dengan kehendak Tuhan. Perbuatan Tuhan hendaknya dipahami dan dilakukan oleh bangsa Israel dan keturunannya. Musa mengajarkan kepada orang tua bangsa Israel agar mereka mengajarkan 
perbuatan Allah kepada anak mereka (Ulangan 6:6-9). Hal ini berarti orang tua sebagai bagian dari umat Allah di tugaskan untuk mengajarkan tentang Allah kepada anak-anaknya. Pengajaran itu dilaksanakan secara lisan dan tidak di batasi oleh ruang dan waktu. Jelaslah bahwa keluarga merupakan tempat yang pertama dimana anak-anak memperoleh pendidikan dan pengajaran, sehingga anak-anak mengenal Allah sebagai penciptanya. Para orang tua harus tekun mengajar kepada anak-anak mereka, karena Allah sendiri yang mengamanatkan tugas itu sebagai tanggung jawab orang tua. Melalui keluarga, Tuhan memberi mandat khusus kepada orang tua untuk memelihara dan mendidik anak-anak sesuai dengan perintah dan kehendak Allah. Orang tua merupakan mitra Tuhan untuk menyampaikan berita keselamatan kepada anak-anak. Dengan pemahaman akan firman Tuhan benar, maka anakanak akan memiliki fondasi yang kuat yang akan memampukannya untuk berdiri sebagaibangunan Allah yang kokoh dan juga dapat menampakkan hidup rohaninya yang nampak dalam sikap dan perilakunya mengajarkan firman Tuhan kepada anak perlu dilakukan secara berulangulang, tidak bosan-bosan karena ini akan memudahkan anak untuk mengerti apa yang kita ajarkan.

Di dalam mendidik anak seharusnya bukan hanya banyak bicara tetapi sebagai orang tua lebih banyak meneladani atau memberikan teladan kepada anak. Jadi seandainya kita mengajarkan firman Tuhan, orang tua harus melakukan terlebih dahulu dan memberikan contoh kepada anak dan ini akan lebih memudahkan dalam mengajarkan kepada anak.

Anak sejak kecil sudah bisa mengerti atau tanggap terhadap teladan yang diberikan orangtua, misalnya diajarkan berdoa.

Namun ketika anak sudah mulai lebih besar saya mengajarkan tentang kesaksian hidup, hidup yang dipimpin Tuhan, hidup di dalam Tuhan dan juga mengajarkan tentang melakukan firman Tuhan di dalam kehidupan yang sebenarnya.

Mengajarkan firman Tuhan secara berulang-ulang juga bisa dilakukan dalam ibadah keluarga yaitu dengan bersama-sama membaca firman Tuhan. Selain di dalam rumah, firman Tuhan juga dapat diajarkan di luar rumah, misalnya pada saat di perjalanan sambil melihat ciptaan Tuhan orangtua mengajarkan atau menceritakan firman Tuhan, menghubungkan firman Tuhan dengan kehidupan nyata.

6. Menceritakan contoh- contoh hidup hamba- hamba Tuhan dari Alkitab (1Sam. 3:1-21)

1. Samuel adalah seorang nabiyang dipakai oleh Tuhan secara luar biasa karena:

a. Dilahirkan dari doa seorang ibu (hana)

b. Dibesarkan dengan jubah dari orang tua, jubah melambangkan gambar diri yang terbentuk dari cara orang tua mengarahkan Samuel untuk menjadi seorang pelayan.

2. Yoas, Raja (Dalam PB, Raja sering disebut juga Rasul) sejak kecil (2 RajaRaja 11:21-12:1,2)Yoas adalah raja yang memerintah sejak umur 7 tahun. Sejak bayi hingga berumur 7 tahun, Yoas tinggal di bait Allah dan hidup dari Firman Tuhan terus-menerus.

3. Yohanes Pembabtis adalah penginjil yang penuh Roh Kudus sejak dalam kandungan, karena:

a. Orang tuanya adalah orang yang hidup takut akan Tuhan, dan adalah orang tua yang dipenuhi Roh Kudus (Luk 1:5-6, Luk 1:41, Luk 1:67) 
b. Dijaga kekudusannya sejak dari kandungan (Luk 1:15) Didikan dimulai sejak dari kandungan

4. Timotius menjadi seorang pengajar kitab suci yang handal, karma sejak kecil dididik mengenal Firman Tuhan (II Tim 3:15)

5. Yesus, adalah gembala yang penuh dengan hikmat sejak kecil. Yusuf dan Maria sangat mentaati Firman Tuhan, taurat Musa, dalam mendidik Yesus, dan dalam umur 12 tahun, Yesus dapat bersoal jawab dengan ahli-ahli taurat. Yusuf adalah seorang laki-laki yang sangat menguasai diri (Mat 1:25), sedangkan Maria adalah seorang hamba Tuhan yang penuh dengan penyerahan hidup (Luk 1:38).

6. Mengajarkan mengasihi Tuhan Yesus dan sesamanya (Mat. 22:36-39).Dalam aspek pendidikan anak, Alkitab memberikan penekanan lebih serius kepada bapak-bapak. Ada 3 alasan yang mendasari penekanan ini:

Pertama, Alkitab mengatakan bahwa pendidikan anak adalah tugas penting yang tidak boleh diabaikan bapak. Seorang ayah tidak bisa meninggalkan tanggung jawab pendidikan anak dan menyerahkan seluruh aspek pendidikan kepada ibu karena dia sendiri berperan sebagai wakil Allah dalam keluarga. Rasul Paulus mengatakan, suami adalah kepala bagi isteri sama seperti Kristus adalah Kepala bagi jemaat.

Kedua, anak belajar mengenal Allah melalui figur ayah. Kalau seorang anak mempunyai konsep yang salah tentang ayahnya, maka konsepnya tentang Allah pun salah.

Ketiga, yang seringkali membuat anak marah dan sakit hati adalah ayah. Tentu saja tidak semua ayah berbuat demikian. Tetapi di dalam masyarakat, yang paling sering menganiaya anak adalah ayah.
Karena itulah Alkitab mengatakan, "Hai bapa-bapa, janganlah sakiti hati anakmu." Maka dalam mendidik anak, yang paling utama adalah diperlukan adanya keteladan dari para orang tua. Kalau para orang tua mampu menunjukkan teladan yang baik, yang berdasarkan ketaatan pada Firman Tuhan serta membina hubungan yang baik antara suami dan isteri berdasarkan kasih Kristus, akan menumbuhkan anak-anak yang taat kepada Tuhan dan kepada orangtuanya. Sebaliknya, kalau para orang tua menunjukkan perilaku yang buruk dalam hubungannya dengan Tuhan, dengan sesama bahkan dengan keluarganya sendiri, akan menumbuhkan perilaku yang buruk pula dalam pribadi anak. Dalam Amsal 6: 20-29, dijelaskan bahwa beberapa contoh buruk yang dapat merusak perilaku anak adalah dosa perzinahan. Orang tua yang tidak mampu memberikan teladan akan menghasilkan anak-anak yang tidak bisa jadi teladan pula. Di satu sisi mereka diajar bahwa tidak setia kepada pasangan, mabukmabukan, berjudi, memakai narkoba adalah sesuatu yang salah dan harus dijauhi. Namun di sisi lain mereka mengetahui bahwa orangtua mereka sendiri melakukannya. Anak-anak semacam ini akan menjadi bingung, gamang, malu, sakit hati, sedih, marah dan juga berontak. Tak jarang mereka meniru apa yang dilakukan oleh orangtua mereka sebagai wujud dari protes. Bentuk lain dari perlakuan negatif dari orangtua yang dapat merusak pribadi anak-anak adalah hukuman (fisik dan omelan) yang berlebihan kepada anak, perlakuan pilih kasih, ketiadaan tatkala sang anak membutuhkan kehadiran orangtua, tuntutan terus-menerus tanpa pujian, atau terlalu memproteksi anak sehingga mereka tidak belajar untuk mandiri. Kata "membangkitkan" berarti 
membuat jadi jengkel, membuat tidak berdaya, memanas-manasi, dan lain-lain. Hal ini dilakukan dengan cara yang salah, yaitu kuasa yang berlebihan, tidak masuk akal, kasar, tuntutan yang kejam, larangan yang tidak perlu. Provokasi semacam ini akan mengakibatkan reaksi yang tidak baik, menumpulkan perasaan, menghilangkan kemauannya untuk halhal yang suci, dan membuat dia merasa tidak mungkin bisa memuaskan orangtuanya. Orangtua yang bijaksana berusaha membuat ketaatan sebagai sesuatu yang didambakan dan diperoleh dengan cinta kasih dan kelemahlembutan. Orangtua tidak boleh menjadi penindas yang tidak berTuhan.

7. Memberi contoh anak-anaknya agar ikut melayani Tuhan (Yoh. 12:26). Orangtua harus memberikan contoh atau teladan yang baik bagi anak-anaknya baik itu melalui sikap dan tindakan orang tua dalam kesehariannya, sehingga dapat menjadi panutan yang baik bagi tumbuh kembang seorang anak dalam sebuah keluarga yang sehat dan harmonis baik dari segi jasmani maupun dari segi spiritual.

Menurut Singgih (2011: 67-70) Tahaptahap perkembangan moral anak dan peranan orang tua. Seperti halnya kita tidak mungkin mengharapkan seorang anak yang baru berusia beberapa nulan untuk dapat berjalan sendiri, demikian pula dengan perkembangan moral. Anak tidak mungkin diharapkan untuk dalam waktu yang relative singkat, tahu dan mengerti bagaimana ia harus bertingkahlaku, bersikap dan hidup bermasyarakat dengan orang lain dalam lingkungannya. Perkembangan moral seorang anak berlangsung secara bertahap, dimana tahap yang satu hanya dapat dicapai apabila tahap sebelumnya telah dilampaui anak. Tiap-tiap tahap itu mempunyai karakteristik-karakteristik tertentu, namun pada umumnya sulit untuk menenukan batas- batas yang jelas antara tahap yang satu dengan yang lainnya. J. Piaget dan L. Kohlberg mengatakan bahwa perkembangan moral seorang anak sejalan dengan perkembangkan aspek kognitifnya. Dengan makin bertambahnya tingkat pengertian anak, makin banyak pula nilai- nilai moral yang dapat ditangkap dan dimengerti oleh anak.

Tahap usia 0-3 tahun

Telah dikatakan bahwa seorang anak dilahirkan tanpa membawa bekal pengertian akan apa yang baik dan yang tidak baik, dalam lingkungan dimana ia hidup. Pada masa ini, yaitu masa usia anak masih sangat muda, tingakah laku itu tentunya mengundang reaksi dari lingkungan sekitar anak. Anak yang merasa mendapat akibat yang menyenangkan dari tingkah lakunya, cenderung untuk menulangi kembali tingkah laku tersebut. Sebaliknya apabila tingkah laku mendatangkan perasaan yang tidak menyenangkan atau menyakitkan, maka ia cenderung untuk mengulangi tingkah laku tersebut. Anak tidak bertingkah laku demikian lagi semata-mata untuk menghindari hukuman (perasaan tidak enak) yang akan diteimanya apabila tingkah laku tersebut dilakukannya.

Pada masa-masa ini, anak melihat orang tua sebagai otoritas yang muthlak dan tidak dapat diganggu gugat. Apa yang ditentukan orang tua harus dituruti oleh anak. Menyadari hal ini, orang tua berperan besar dalam membimbing dan mengarahkan tingkah laku anak. Dengan adanya konsistensi dalam tingkah laku sikap orang tua terhadap apa yang mendatangkan pujian atau hukuman (keadaan yang tidak menyenanngkan) bagi anak, cenderung membuat anak berusaha menghindari diri dari berbuat sesuatu yang dapat mendatangkan hukumman atau keadaan tidak enak tersebut.

Contoh: 
Seorang anak yang semula berusaha merebut mainan milik siapapun yang dilihatnya dan karena ia menyenangi lamakelamaan ia tahu bahwa apa yang bukan miliknya tidak boleh diambol atua dimiliki, anak lambat laun belajar menghargai milik orang lain.

Tahap usia 3-6 tahun.

Pada masa ini anak sudah memiliki dasar- dasar dari sikap moralitas terhadap kelompok sosialnya kalau sebelumnya anak selalu diajarkan tentang apa yang benar dana pa yang salah, maka pada masa ini anak harus lebih ditunjukkan mengenai bagaimana ia harus bertingkah laku. Anak harus dpat merasakan akibat yang menyenangkan dari tingakah lakunya yang sesuai dengan harapan kelompok sosial, demikian pula akibat yang tidak menyenangkan apabila ia tidak berlaku demikian. Anak juga dapat mengenal suatu tindakan itu baik, dari hadiah yang dijanjikan oleh orang lain. Artinya anak tau bahwa tindkanya itu benar jika dengan tindakannnya itu kebutuhannya terpuaskan.

Contoh:

Anak mau membagi sebagian dari kue yang dimilikinya kepada adeknya, semata-mata untuk mendapatkan ke lain yang dijanjikan oleh ibunya apabila ia berlaku demikian. Hadi masa ini, anak dapat memperlihatkan suatu perbuatan yang baik, tapi masih tanpa pengetahuan mengapa ia harus berbuat demikian.

Ia melakukan hal ini untuk menghindari hukuman yang mungkin akan dialami dari lingkungan sosial, atau untuk memperoleh pujian atau untuk pemenuhan kebutuhannya. Peranan orangtua sayang besar dalam mendisiplinkan untuk berbuat baik. Dengan adanya rangsanganrangsangan dari orangtua untuk anak berbuat baik, diharapkan bahwa pada anak dapat tertanam nilai- nilai moral yang baik.
Tahap Usia Remaja

Menjelang usia remaja, anak sudah mengembangkan nilai- nilai moral sebagai hasil dari pengalaman- pengalaman di rumah dan dalam hubungnannya dengan anak - anak lain. Nilai- nilai ini sebagian akan menetap dan mempengaruhi tingkahtingkah lakunya, dan sebagian lainnya akan mengalami perubahan akibat pengaruh lingkungan tersebut. Dengan demikian dapat dikatakan bahwa terhadap perkembangan moral anak, orang tua mempunyai peran penting, baik secara langsung maupun tidak langsung.

Menurut Anwar, (153 : 2011) Keluarga merupakan tempat pendidikan pertama yang bersifat alamiah, karena dalam lingkungan keluarga seorang anak mulai mendapatkan pendidikan untuk yang pertama kalinya. Dalam keluargalah anak dipersiapkan mengalami tingkatan perkembangannya untuk memasuki dunia lainnya seperti dunia orang dewasa, bahasa adat istiadat dna kebudayaan. Disamping keluarga, masyarakat menjadi tempat pendidikan yang pertama yang bersifat alamiah.

Keluarga merupakan pendidikan yang pertama yang menyediakan kebutuhan biologis bagi anak dan sekaligus memebrikan pendidikannya, sehingga menghasilkan pribadi-pribadi yang dapat hidup dalam masyarakat sambil menerima dan mengolah serta mewariskan kebudayaannya.

Keluarga merupakan unit terkecil dalam masyarakat yang terdiri dari ayah, ibu, dan anak yang belum menikah. Di dalam kehidupan masyarakat dimanapun mempunyai fungsi yang sangat penting di dalam kelangsungan hidup bermasyarakat, didalam malah ini akan dibahas tentang peranan sebagai lingkungan pendidikan anak.

Di dalam pendidikan anak dalam keluarga perlu diperhatikan dalam 
memberikan kasih sayang, jangn berlebihlebih dan jangan pula kurang. Oleh karena itu keluarga harus pandai dan tepat dalam memberikan kasih sayang yang dibutuhkan oleh anaknya. Pendidikan keluarga yang baik adalah: pendidikan yang memberikan dorongan kuat kepada anaknya untuk mendapatkan pendidikan-pendidika agama.

Pendidikan keluarga mempunyai pengaruh yang penting untuk mendidik anak. Hal tersebut mempunyai pengaruh yang positif dimana lingkungan keluarga memebrikan dorongan atau memberikan motivasi yang positif diamna lingkungna keluarga memberikan dorongan atua memberikan motivasi dan rangsangan untuk menerima, memahami, meyakini, serta mengamalkan ajaran kepercayaannya. Oleh karena itu ada beberapa aspek pendidikan yang sangat penting untuk diberikan dan diperhatikan orangtua, di antaranya:

Peran keluarga dalam pendidikan anak dapat dilakukan dengan beberapa pola, yaitu:

1. Bermain pada anak

Bermain merupakan salah satu cara yang tepat untuk melepaskan atau menumpahkan seluruh energy dan perasaan yang dimiliki anak termasuk didalamnya emosi anak. Selain itu biasanya dengan bermain anak juga dapat menghasilkan hubungan sosial mereka.

2. Permainan peran yang dapat melatih kecerdasan sosial emosional antara lain:

a. Bermain peran dengan boneka tangan maupun wayang

b. Film pembelajaran bermuatan nilai sosial emosional.

c. Ajak anak kelaur rumah untuk berinteraksi dengan orang lain

d. Ajak anak bermain kelompok (cooperative play), seperti: sepak bola

e. Sentuhan, belaian dan pelukan kepada anak

Interaksi antara oang tua dengan anak sangat berpengaruh terhadap kecerdasan sosial emosional anak. Sentuhan, belaian dan pelukan yang diberikan kepada anak merupakan cara yang tepat untuk membangun hubungna baik atau kelekatan anatara orang tua dengan anak

Kata positip yang diberikan kepada anak membuat anak termotivasi untuk melakukan dan mengulangi perikaku yang positif dan membuat anak percaya diri. Sedangakan empati dari orang tua membuat anak merasa orang tua berada di pihaknya, terutama saat anak memiliki masalah, empati dari orang tua sangatlah penting agar anak dapat lebih tenang dan merasa orang tua merasakan apa yang anak rasakan.

Keluarga menjalankan peranannya sebagai suatu sistem sosial yang dpat membentuk karakter serta moral seorang anak. Keluarga tidak hanya sebuath wadah tempat berkumpulnya ayah, ibu, dan anak. Sebuah keluarga sesungguhnya lebih dari itu. Keluarga merupakan tempat ternyaman bagi anak. Berawal dari keluarga segala sesuatu berkembang. Kemampuan untuk bersosialisasi, mengaktualisasikan diri, berpendapat, hingga periaku yang menyimpang. Menurut Buku Tafsiran Alkitab Masa Kini 3 Matius - Wahyu, (2003: 604 - 605)

Pentingnya pengajaran firman Tuhan

Dalam Perjanjian Lama kita dapat mengerti bahwa, keluarga adalah tempat yang pertama pendidikan agama diberikan. Sebelum adanya hukum-hukum Musa, kaum Lewi ditetapkan sebagai imam, para nenek moyang Israel yang menjadi imam atas kaum keluarganya, memimpin keluarganya mempersembahkan korbankorban ke hadirat Allah. Peranan keluarga para nenek moyang Israel yaitu Abraham, Ishak dan Yakub, besar sekali pengaruhnya terhadap hidup anggota keluarga dan keturunannya. Nenek moyang bangsa Israel menjadi guru bagi seluruh keluarganya yaitu mengajar perbuatan-perbuatan Allah yang 
besar dan janjiNya membawa berkat bagi bangsa itu turun-temurun.

Orang tua mempunyai tugas yang sama dengan para nabi dan imam yaitu menyampaikan dan meneruskan berita tentang karya keselamatan Allah kepada anak-anak. Ini merupakan tugas yang sangat penting dari orang tua, oleh karena itu Allah memanggil mereka sebagai orang tua.Pendidikan bangsa Israel dipusatkan dalam keluarga. Bagi umat Israel, keluarga adalah tempat yang penting dan utama dalam menerapkan pendidikan bagi anak dan ayah bertanggung jawab dalam mendidik anak-anak. Kitab Amsal merupakan kitab didikan. Banyak nasehat yang diberikan kepada anak-anak, yang intinya agar mereka mendengarkan, mentaati dan menuruti didikan ayah maupun ibunya, Dasar didikan itu ialah takut akan Tuhan (Amsal 1: 7). Dalam pendidikan Israel, ibu-ibu tidak dibebaskan dari tanggung jawab dalam pendidikan anakanak, mereka aktif mendidik anak-anak perempuan dengan berbagai keterampilan seperti: memasak, menenun, membuat karya-karya seni.

Demikian anak-anak juga didorong untuk mendengar pengajaran dari ayah dan tidak meninggalkan ajaran ibunya (Amsal 1:8). Ayat itu mempunyai tujuan yang sama dalam membina rohani anak.

\section{SIMPULAN}

Allah memberikan anak-anak kepada setiap orang tua dan Allah menghendaki agar mereka beserta anak-anaknya melayani Dia. Dalam arti bahwa Allah memberikan mereka bukan supaya kita dapat memiliki mereka untuk kepentingan pribadi, tetapi Allah memberikan kepada setiap orang tua (keluarga) supaya mereka dibesarkan demi kemuliaan nama Tuhan, karena anak adalah karunia yang diberikan kepada setiap orang tua.Tuhan Yesus menyambut anakanak yang datang kepadanya. Bahkan pentingnya memperhatikan anak, sehingga Tuhan Yesus memberikan sangsi yang sangat keras yaitu menenggelamkan ke dalam laut (Matius 18:1-6) Tuhan Yesus sendiri sebagai Anak menunjukkan ketaatan-Nya kepada Bapa yang di sorga (Yoh. 5:36; 8:19, 42, 49).

Dalam Efesus 6 : 4, mengandung pengertian bahwa "Allah mau anak-anak dibesarkan dalam ajaranNya". Dalam ayat mi kewajiban seorang ayah sangat diperlihatkan baik secara positif maupun negatif, makna pertama dalam ayat ke empat adalah peringatan kepada bapa-bapa agar jangan menyakiti hati anak-anaknya, makna kedua adalah perintah untuk melatih anakanak dalam pendidikan disiplin hidup Kristen. Terdapat cara-cara pengajaran Firman Tuhan:

Dalam Kitab Ulangan 6: 6-9 sangat rinci dan jelas bagaimana bangsa Israel mengajarkan firman Tuhan kepada anakanaknya ;

1. Mengajarkan secara berulang-ulang

2. Membicarakan di berbagai kesempatan, baik saat santai, bangun tidur maupun dalam perjalanan

3. Mengajarkan dengan menggunakan tanda pengingat yang berupa tali di tangan, lambing di dahi dan tulisan pada tiang pintu dan pada pintu gerbang.

Orangtua harus dapat menjadi teladan bagi anak- anaknya, misalnya teladan dalam membaca Alkitab, teladan berdoa, teladan ke Gereja, teladan dalam mentaati perintahperintah Tuhan (1Ptr. 2:21). Orangtua yang dapat menajdi contoh bagi anak-anaknya, sungguh akan menyelamatkan anakanaknya. Misalnya: Ibu Lois dan Eunike (2 Tim. 1:5). Orangtua harus menjadi teladan bagi anak-anaknya dalam perkataan, tingkah laku, kasih, kesetiaan dan kekudusan (1Tim. 4:12).

\section{DAFTAR PUSTAKA}


[1] Anwar.(2005).Pendidikan Anak Usia Dini. Bandung: Alfabeta.

[2] Amin, M. dan Najib, M. (1993). Agama, Demokrasi dan Transformasi Sosial. Yogyakarta: LPKSMNV DIY.

[3] Hurloch, E. B. (1978). Perkembangan Anak, Jilid II. Jakarta: Erlangga.

[4] Kristianto, P. L. (2006). Prinsip \& Praktik Pendidikan Agama Kristen. Yogyakarta: ANDI.

[5] Reni, H. A. (2001). Psikologi Perkembangan Anak. Jakarta: PT. Grasindo.

[6] Setiawan, M. G. (2000). Menerobos Dunia Anak. Bandung: Yayasan Kalam Hidup.

[7] Sidjabat, B.S. (2008). Membesarkan Anak dengan Kreatif. Yogyakarta: ANDI.

[8] Singgih, G. (1987). Dasar dan Teori Perkembangan anak. Jakarta: BPKGunung Mulia.

[9] ____ (2011). Psikologi Perkembangan Anak dan Remaja. Jakarta: BPKGunung Mulia.

[10] Wahyu.(2003). Tafsiran Alkitab Masa Kini 3 Matius-Wahyu. Jakarta: Yayasan Kanonisasi Bina Kasih.

[11] Yusuf, S. Psikologi Perkembangan Anak dan Remaja. Jakarta: Rineka Cipta. 